\title{
Oxidation of various potential energy sources by the methanotrophic endosymbionts of Siboglinum poseidoni (Pogonophora)
}

\author{
Rolf Schmaljohann \\ Institut für Meereskunde an der Universität Kiel, Düsternbrooker Weg 20, W-2300 Kiel, Germany
}

\begin{abstract}
The small pogonophore Siboglinum poseidoni, which lives in symbiosis with intracellular methanotrophic bacteria, was investigated with respect to its oxidation of higher homologues of methane. Ethane and propane were readily consumed if supplied together with methane and, at a considerably lower rate, in the absence of methane. Consumption of butane could not be detected. The addition of ethane or propane in equal amounts to methane always resulted in a decrease in methane consumption rate. Like all methanotrophic bacteria the endosymbionts of $S$. poseidoni are also capable of ammonia oxidation. Homogenates of bacteria-containing posterior parts of this organism incubated with ammonia or hydroxylamine oxidized these compounds to nitrite, while symbiont-free anterior parts were nearly inactive in this respect. Ammonia in high concentrations $(>0.05 \%)$ had an inhibitory effect on methane oxidation rates of $S$. poseidoni. The relevance of these activities in the natural habitat of this pogonophore is discussed. Since ethane and propane are present only as constituents of gas adsorbed to sediment particles and only in low concentrations compared to methane, the in situ utilization of these compounds is unlikely. Ammonia, however, being present at concentrations about 2 orders of magnitude higher than those of methane, could well serve as an additional energy source, especially in periods of low methane supply.
\end{abstract}

\section{INTRODUCTION}

The small pogonophore Siboglinum poseidoni has been shown to live in symbiosis with intracellular methanotrophic bacteria. This was established by ${ }^{14} \mathrm{CH}_{4}$ uptake experiments and electron micrographs showing extensive intracellular membrane stacks typical of type I methanotrophs (Schmaljohann \& Flügel 1987). These results were confirmed by stable carbon isotope analyses of pogonophoran tissues indicating that most of the cell carbon originated from biogenic methane, and by enzyme assays showing the presence of methanol dehydrogenase and hexulosephosphate synthetase (Schmaljohann et al. 1990).

Free-living obligate methanotrophic bacteria are known to co-oxidize a variety of other compounds during growth on methane (Whittenbury et al. 1970, Stirling \& Dalton 1979) or during non-growth conditions without methane (Leadbetter \& Foster 1960). These compounds include ethane, propane, butane and ammonia, which are present in the natural habitat of Siboglinum poseidoni in low concentrations and could be used as additional energy sources, especially when methane is limited.
The present study investigates whether low-molecular-weight alkanes or ammonia can be co-oxidized as additional energy sources by symbiotic methanotrophs and examines the influence of these compounds on methane oxidation rates.

\section{MATERIAL AND METHODS}

Consumption of light hydrocarbons. The Pogonophora used for these experiments were collected with a beam trawl (Flügel \& Langhof 1983) at 2 stations in the central Skagerrak (Siboglinum poseidoni: $58^{\circ} 01.3^{\prime} \mathrm{N}$, $09^{\circ} 34.6^{\prime} \mathrm{E}, 300 \mathrm{~m}$ water depth; Siboglinum ekmani: $58^{\circ} 11.5^{\prime} \mathrm{N}, 09^{\circ} 58.0^{\prime} \mathrm{E}, 440 \mathrm{~m}$ ). After keeping the worms for 3 or $4 \mathrm{~d}$ in seawater at $5^{\circ} \mathrm{C}$, healthy-looking individuals were sorted out, cleansed of adhering mud and rinsed twice in membrane-filtered $(0.2 \mu \mathrm{m})$ seawater. Groups of 50 individuals were put into $58 \mathrm{ml}$ crimp vials filled with $0.2 \mu \mathrm{m}$ filtered seawater. After adjusting the headspace to exactly $5 \mathrm{ml}$ the vials were sealed and the gaseous hydrocarbons were added by injection through the seal. The purity of the hydrocarbons was as follows: methane, $99.995 \%$; ethane and 
propane, 99.95\%; butane, 99.5\%. In Expt 1 each vial contained the same amount of $1 \%$ hydrocarbon $(\mathrm{v} / \mathrm{v})$ in air. As solubilities of methane, ethane, propane and butane in water differ considerably, this resulted in different hydrocarbon concentrations in the incubation medium (Table 1). Solubilities of 3 of these hydrocarbons are known only for pure water and, in the case of methane, also for seawater (Wen \& Hung 1970 , Wiesenberg \& Guinasso 1979). Therefore the solubility of ethane, propane and butane in seawater can only be roughly estimated, assuming the seawater salts cause a similar reduction in solubility as for methane (Table 1 ). At the incubation temperature of $7^{\circ} \mathrm{C}$ solubility is highest for ethane, decreasing for propane, butane and methane. To account for the different solubilities of hydrocarbons, roughly equal concentrations of the gases in solution were established in Expt 2, which meant a different concentration of each hydrocarbon in the headspace (Table 1).

During incubation the decrease in hydrocarbon concentration in the headspace was monitored by daily sampling of $0.1 \mathrm{ml}$ gas and subsequent analysis in a gas chromatograph (Packard $438 \mathrm{~A}$ ) fitted with a TCD and a $3 \mathrm{~m} \times 1 / 8 \mathrm{in}$. (3.2 mm) Porapak $Q$ column. Helium was used as carrier gas $\left(14 \mathrm{ml} \mathrm{min}^{-1}\right)$. The analysis was carried out at an initial oven temperature of $100^{\circ} \mathrm{C}$, which was raised to $145^{\circ} \mathrm{C}$ over $3 \mathrm{~min}$ by a time program starting after $1 \mathrm{~min}$.

Vials filled with seawater but containing no Pogonophora were used as controls for determining loss of hydrocarbons by adsorption or diffusion through

Table 1. Solubility and concentration of hydrocarbons in the experiments. Vol added: volume of hydrocarbons added to the $5 \mathrm{ml}$ vial headspace; Conc.: resulting concentration in seawater

\begin{tabular}{|c|c|c|c|c|}
\hline & Methane & Ethane & Propane & Butane \\
\hline \multicolumn{5}{|l|}{ Expt 1} \\
\hline Vol added ( $\mu \mathrm{l})$ & 50 & 50 & 50 & 50 \\
\hline Conc $\left(\mu \mathrm{mol} 1^{-1}\right)$ & 11.91 & 16.16 & 14.69 & 13.52 \\
\hline \multicolumn{5}{|l|}{ Expt 2} \\
\hline Vol. added $(\mu \mathrm{l})$ & 143.4 & 105.4 & 115.9 & - \\
\hline Conc. $\left(\mu \mathrm{mol} \mathrm{l} \mathrm{l}^{-1}\right)$ & 34.0 & 34.0 & 34.0 & - \\
\hline $\begin{array}{l}\text { Solubility in pure } \\
\text { water at } 7^{\circ} \mathrm{C} \\
\text { (ml gas } \mathrm{kg}^{-1} \text { water) }\end{array}$ & $47.28^{\mathrm{a}}$ & $75.26^{\star}$ & $64.81^{\text {a }}$ & $57.44^{\mathrm{a}}$ \\
\hline $\begin{array}{l}\text { Solubility in sea- } \\
\text { water at } 7^{\circ} \mathrm{C} \\
\text { (ml gas } l^{-1} \text { seawater) }\end{array}$ & $37.10^{\mathrm{b}}$ & $58.70^{c}$ & $50.55^{\mathrm{c}}$ & $44.80^{\circ}$ \\
\hline \multicolumn{5}{|c|}{ according to Wen \& Hung $(1970)$} \\
\hline \multicolumn{5}{|c|}{ According to Wiesenberg \& Guinasso (1979) } \\
\hline \multicolumn{5}{|c|}{$\begin{array}{l}{ }^{c} \text { Estimated, based on percentage reduction in solubility of } \\
\text { methane by seawater }\end{array}$} \\
\hline
\end{tabular}

the seals. In Expt 2 an additional control was carried out using specimens of a related pogonophoran species (Siboglinum ekmani), which is known to harbour sulphur-oxidizing symbionts and does not possess enzymes for $\mathrm{C}_{1}$ oxidation (Southward et al. 1986). The time needed to establish an equilibrium between gas and liquid phase was at least $24 \mathrm{~h}$. This was because earlier experiments had shown the Pogonophora to be very sensitive to shaking. The incubation was carried out in darkness at $7^{\circ} \mathrm{C}$, while the tubes lay horizontally (maximum fluid depth $2.5 \mathrm{~cm}$ ) to allow gas exchange between the phases to occur as rapidly as possible.

Hydrocarbon uptake rates were calculated from headspace concentrations during the first 5 days after the beginning of the incubation, taking into account the amount of dissolved gas. As the rates remained stable or showed only a slight decrease during this period, the average rate over the $5 \mathrm{~d}$ is reported here. These rates were corrected by subtracting the rates for controls without Pogonophora, and related to pogonophoran wet weight. Gas losses in the control tubes were almost entirely due to removal of hydrocarbons by the repeated sampling. Usually no loss of gas by absorption or leaking could be detected.

Some of the rate determinations in Expt 2 were run in duplicate. The measured rates were within the range of +7 to $14 \%$ of the average given in the figures. The gas chromatographic measurements were done in duplicate, showing an average divergence of $3.3 \%$ between 2 successive analyses.

Influence of ammonia on methane oxidation rates. Collection, cleaning and incubation of Pogonophora was conducted similarly to the hydrocarbon studies. Different ammonia concentrations were prepared by addition of $\mathrm{NH}_{4} \mathrm{Cl}(0.05,0.1$, and $0.5 \% \mathrm{w} / \mathrm{v})$. The amount of ammonia present in the natural seawater (less then $10^{-5} \%$ ) was neglected. After sealing the tubes $1 \%$ methane was injected through the septum, and methane consumption was measured daily during the first $5 \mathrm{~d}$ of incubation.

Ammonia concentration in sediment of the habitat of Siboglinum poseidoni was measured by suspending $10 \mathrm{ml}$ of sediment in $100 \mathrm{ml}$ of $3.5 \% \mathrm{NaCl}$ solution and subsequently determinating ammonia by the method of Grasshoff (1964).

Assays for nitrifying enzymes. Freshly sampled Siboglinum poseidoni were pulled out of their tubes and separated into anterior parts (without endosymbionts) and posterior parts containing the trophosome with the symbiotic bacteria. Groups of 30 to 50 specimens were put into $0.5 \mathrm{ml}$ of $0.2 \mu \mathrm{m}$ filtered seawater and frozen in liquid nitrogen. After thawing, the pogonophoran tissue was ruptured by gentle treatment with a glass homogenizer and centrifuged for $10 \mathrm{~min}$ at $12000 \times g$. Bacteria in the pellet were afterwards re- 
homogenized with $0.5 \mathrm{ml}$ ice-cold distilled water to rupture the bacteria, and this second homogenate was used for the assays.

Assays for nitrifying enzymes were performed according to Dando et al. (1986). Homogenate $(50 \mu \mathrm{l})$ was incubated for $24 \mathrm{~h}$ with $1 \mathrm{ml}$ of $100 \mathrm{M}$ hydroxylamine or $2.5 \mathrm{mM}$ ammonium sulphate in $50 \mathrm{mM}$ diethanolamine, at pH 7.5 and $20^{\circ} \mathrm{C}$. Controls incubated without substrate were used to correct for internal nitrite formation. After incubation, aliquots of the reaction mixture were centrifuged and analyzed for nitrite according to Strickland \& Parsons (1972). Protein contents of the homogenate were determined with the method of Bradford (1976).

\section{RESULTS}

\section{Consumption of hydrocarbons}

In Expt 1 either methane, ethane, propane and butane were added singly at a $1 \%$ concentration to the headspace of the incubation vials, or methane was combined with one of the higher homologues (at an equal concentration in the gas phase). Results are given in Fig. 1. Methane alone was taken up most rapidly by Siboglinum poseidoni, followed by ethane and only minor amounts of propane, while butane was not consumed. If methane was added simultaneously, the amount of ethane and propane taken up was larger than that without methane. Ethane was even preferred to methane in this case, probably because of its higher solubility. Butane, however, could not be taken up even in the presence of methane. Methane consumption in combination with higher alkanes was highest with butane, decreasing for propane and ethane. The difference in uptake rates with methane and butane compared to those with methane alone was not significant.
In Expt 2 equal concentrations of hydrocarbons in solution were applied, and the results for Siboglinum poseidoni (with methanotrophic symbionts) were compared with $S$. ekmani (with sulphur-oxidizing symbionts). As in Expt 1, uptake of methane alone by $S$. poseidoni was higher than that of the other hydrocarbons, and the simultaneous presence of methane enhanced uptake of ethane and propane (Fig. 2). The methane consumption rate was higher than in Expt 1 , probably due to higher methane concentrations, $S$. ekmani produced only a very low decrease in methane, ethane or propane concentrations, apparently due to adsorption of hydrocarbons to the pogonophore tube or to uptake by bacterial contaminants adhering to it. As these low rates are comparable to propane uptake by $S$. poseidoni without methane, propane uptake by this species is also probably not due to oxidation by the symbionts.

\section{Influence of ammonia on methane oxidation rates}

Siboglinum poseidoni individuals incubated without additional ammonia consumed methane at rates comparable to those in Expt 1 (which had an identical methane concentration in the medium) (Table 2). Addition of 0.05 or $0.1 \% \mathrm{NH}_{4} \mathrm{Cl}$ resulted in a decrease in methane uptake rate to $22 \%$, while $0.5 \% \mathrm{NH}_{4} \mathrm{Cl}$ in the medium led to a nearly total breakdown of methane oxidation.

The ammonia concentrations used in this experiment were selected to compare the degree of inhibition with data from Whittenbury et al. (1970), who employed identical concentrations for free-living methanotrophs. Compared to naturally occurring ammonia concentrations in the sediment, which range between 0.1 and $0.7 \mathrm{mM} \mathrm{kg}^{-1}$ wet wt (Table 3) (corresponding to ca 0.002 to $0.015 \% \mathrm{w} / \mathrm{v}$ in pore water), these concentrations are very high.
Fig. 1 Siboglinum poseidoni. Consumption of gaseous alkanes in Expt 1 (incubation with initial concentration of $1 \%$ hydrocarbon in the gas phase). $\mathrm{M}$ : methane; $\mathrm{E}$ : ethane; P: propane; B: butane

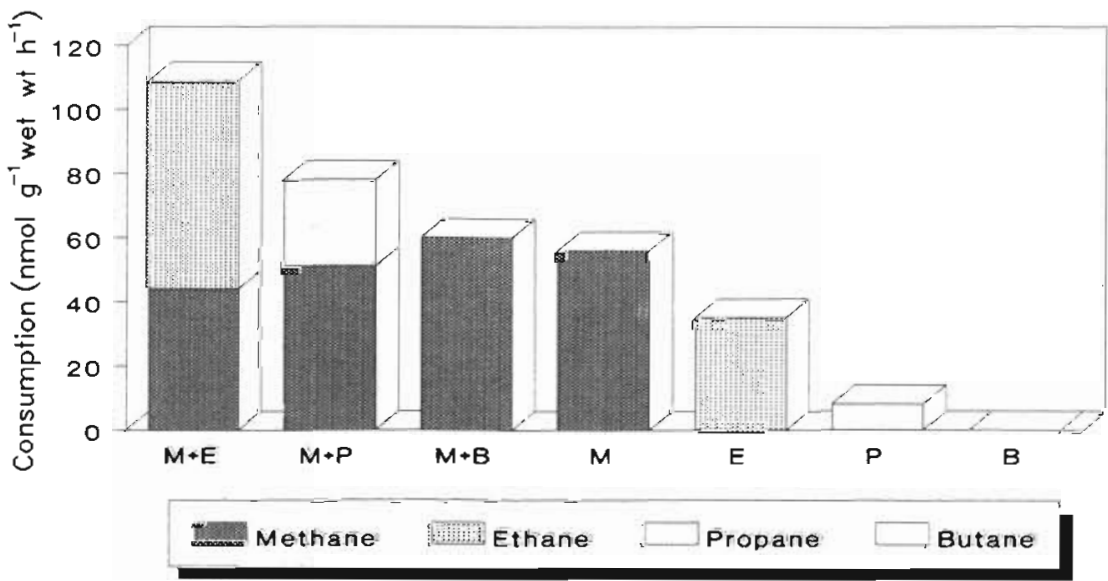




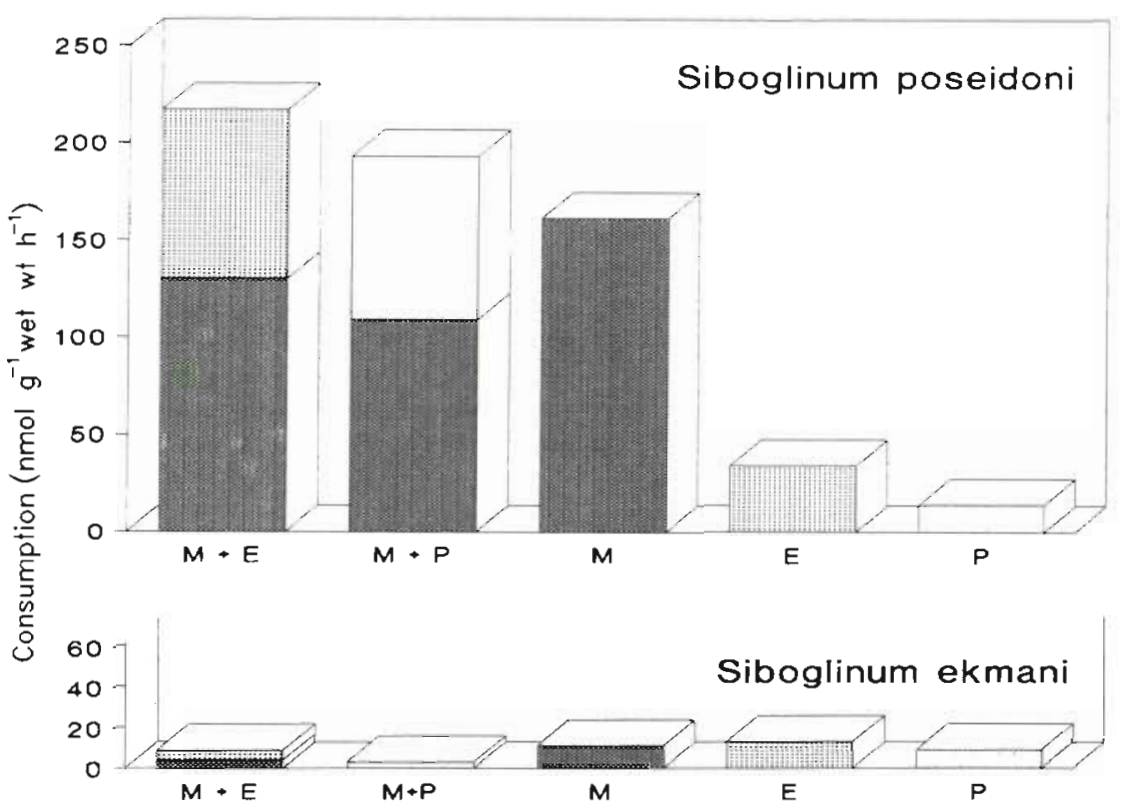

Fig. 2. Siboglinum poseidoni and S. ekmani. Consumption of gaseous alkanes in Expt 2 (incubation with equal concentrations of hydrocarbon in solution) Bar patterns and abbreviations as in Fig. 1

\section{Oxidation of ammonia and hydroxylamine to nitrite}

Homogenates of Siboglinum poseidoni were able to oxidize ammonia as well as hydroxylamine to nitrite (Table 4). This activity was confined to the posterior parts of the Pogonophora, containing the trophosome with methanotrophic endosymbionts. The low activity in the worms' anterior parts was probably due to contamination with trophosome material during prepara-

Table 2. Siboglinum poseidoni. Inhibition of methane oxidation rates by different concentrations of $\mathrm{NH}_{4} \mathrm{Cl}$. Rates are given in $\mathrm{nmol} \mathrm{g}^{-1}$ wet $\mathrm{wt} \mathrm{h}^{-1}$ ( 1 individual corresponds to between 3 and $4 \mathrm{mg}$ ). Groups 1 and 2 were duplicates

\begin{tabular}{|cccc|}
\hline Conc. of $\mathrm{NH}_{4} \mathrm{Cl}$ & Group 1 & Group 2 & Average \\
\hline$<0.00005 \%$ & 60.4 & 69.7 & 65.05 \\
$0.05 \%$ & 13.7 & 14.2 & 13.95 \\
$0.10 \%$ & 14.2 & 14.1 & 14.15 \\
$0.50 \%$ & 0 & 4.7 & 2.35 \\
\hline
\end{tabular}

Table 3. Concentrations of $\mathrm{NH}_{4}{ }^{+}$in Skagerrak sediments containing Siboglinum poseidoni

\begin{tabular}{|cccc|}
\hline $\begin{array}{c}\text { Depth } \\
(\mathrm{cm})\end{array}$ & $\begin{array}{c}\text { Sediment } 1 \\
\mathrm{NH}_{4}^{+}\end{array}$ & $\begin{array}{c}\text { Septh } \\
(\mathrm{cm})\end{array}$ & $\begin{array}{c}\text { Sediment 2 } \\
\mathrm{NH}_{4}^{+}\end{array}$ \\
\hline $0-1$ & 190 & 3 & 123 \\
3 & 300 & 10 & 295 \\
6 & 531 & 20 & 239 \\
10 & 724 & & \\
15 & 426 & & \\
20 & 290 & & \\
\hline
\end{tabular}

tion. Under the assay conditions the amount of nitrite formed from hydroxylamine was about 3 times higher than that from ammonia.

\section{DISCUSSION}

The ability of Siboglinum poseidoni, or rather its methanotrophic endosymbionts, to consume ethane and propane was demonstrated by gas chromatographic analysis. It has been shown for several freeliving obligate methanotrophic bacteria that the enzyme responsible for the first step in methane oxidation, a methane mono-oxygenase, can also oxidize its gaseous homologues ethane, propane and butane, in addition to a number of other compounds (Anthony 1982). These compounds cannot be used as the sole carbon source by obligate methanotrophs, but they can be oxidized and used as additional energy sources. It has been shown by Davidova ef al. (1988) that during growth of Methylococcus capsulatus in a gaseous mixture containing methane and ethane the latter is primarily oxidized to water-soluble products which are released to the medium. According to Leadbetter \& Foster (1960) these are mainly ethanol, acetaldehyde and acetic acid. Especially in the case of an endosymbiosis these exudates could be directly used by the host. A similar excretion of metabolites also occurs during methane oxidation (Higgins et al. 1982).

An inhibitory effect of ethane and propane on methane consumption has been reported by several authors (Leadbetter \& Foster 1960, Davidova et al. 1988). This inhibition was not effective if the released metabolites were removed by an associate culture, 
Table 4. Siboglinum poseidoni. Formation of nitrite (nmol $\mathrm{mg}^{-1}$ protein $\mathrm{d}^{-1}$ ) from ammonia or hydroxylamine by homogenates of pogonophores. Values are results of duplicate measurements

\begin{tabular}{|c|c|c|}
\hline Substrate & $\left(\mathrm{NH}_{4}\right)_{2} \mathrm{SO}_{4}$ & $\mathrm{NH}_{2} \mathrm{OH}$ \\
\hline Posterior parts & $11.8 ; 13.2$ & $32.4 ; 34.6$ \\
\hline Anterior parts & $3.0 ; 3.1$ & $2.2 ; \quad 1.8$ \\
\hline
\end{tabular}

indicating that not only the substrate competition is important but also an inhibition by the released metabolites. In this respect as well, an endosymbiosis could favour the co-oxidation of gaseous alkanes.

The hydrocarbon uptake rates found in the present experiments cannot be extrapolated to in situ conditions. Natural concentrations of ethane, propane and butane in the habitat of Siboglinum poseidoni are much lower than that of methane. Free gases extracted from pore water contained no measurable $\mathrm{C}_{2+}$ hydrocarbons, whereas gas adsorbed to sediment amounted to $86.7 \mathrm{ppb}$ methane, $7.1 \mathrm{ppb}$ ethane, $2.8 \mathrm{ppb}$ propane and $1.9 \mathrm{ppb}$ butane (w/w) (Schmaljohann et al. 1990). In areas where thermogenic gas seeps from the sediment the gaseous alkanes are much more important. Anderson et al. (1983) report $\mathrm{C}_{1} /$ $\mathrm{C}_{2}+\mathrm{C}_{3}$ ratios between 0.52 and 56.5 for the Louisiana (USA) slope seeps. It would be interesting to investigate the impact of these compounds on the symbiosis between mytilid mussels and methanotrophs occurring in this area (Childress et al. 1986).

The finding that methane oxidation by Siboglinum poseidoni is inhibited by ammonia is consistent with reports from free-living methanotrophs. Whittenbury et al. (1970), who applied the same $\mathrm{NH}_{4} \mathrm{Cl}$ concentrations to cultures of Methylosinus trichosporium strain OB 3B, noted that methane oxidation rates with $0.05 \% \mathrm{NH}_{4} \mathrm{Cl}$ in the medium decreased to $\mathrm{ca} 73 \%$ and with $0.5 \%$ $\mathrm{NH}_{4} \mathrm{Cl}$ to $7 \%$, of rates without addition of ammonia. These authors observed similar ratios for other methanotroph strains. This comparison shows that the symbionts of $S$. poseidoni behave like true methanotrophs and that the host obviously does not hinder high ammonia concentrations from entering through its tissue.

The nitrification rates obtained from assays with homogenates of Siboglinum poseidoni are qualitative rather than quantitative in nature. Oxidation rates cannot be compared with those found e.g. by Dalton (1977) for crude extracts of Methylococcus capsulatus, because of the long incubation time applied and different assay parameters in the present study. But the data clearly indicate that nitrifying activity associated with the symbionts in the posterior parts of Pogonophora occurs, which is lacking in the bacteria-free anterior parts. These data show for the first time that endosymbiotic bacteria in marine invertebrates can also oxidize potential energy sources other than methane or reduced sulphur compounds. Dando et al. (1986), applying the same assay to several symbiotic associations including Pogonophora and bivalves in a Norwegian fjord, did not find any nitrifying activity in these organisms.

The higher activity observed for hydroxylamine oxidation compared to ammonia oxidation might be explained by the observation of Dalton (1977) that there was always a lag phase before nitrite was formed from ammonia, and that a certain concentration of hydroxylamine (ca $0.25 \mathrm{mM}$ ) had to be formed from ammonia before nitrite could be formed.

Ammonia oxidation by methanotrophs has also been reported by other authors (Dalton 1977, O'Neill \& Wilkinson 1977. Romanovskaya et al. 1977). The data suggest that nitrification is a normal element of the metabolism of methanotrophs, supplying these organisms with an additional source of energy. Though some obligate methanotroph strains possess ribulosebisphosphate-carboxylase (Methylococcus capsulatus), they are not capable of autotrophic growth in the absence of methane and with $\mathrm{NH}_{4}{ }^{+}$as their energy source, as are ammonia-oxidizing bacteria (Stanley \& Dalton 1982). There are also ammonia-oxidizing bacteria such as Nitrosococcus oceanus that are able to obtain energy from the oxidation of methane to $\mathrm{CO}_{2}$ and to incorporate this into cell carbon. These bacteria have a high affinity to methane and can metabolize it at rates approximately equal to ammonia during ammonia oxidation (Ward 1987). As these organisms also have internal membrane systems quite similar to those of the endosymbionts of Siboglinum poseidoni, it could be suggested that the symbionts are in reality ammoniaoxidizing bacteria. It has, however, been shown that the bulk of cell carbon in $S$. poseidoni originates from biogenic methane, which is evident from the extremely ${ }^{13} \mathrm{C}$-depleted state of its cell carbon (Schmaljohann et al. 1990). Nitrifying bacteria cannot grow on methane as the sole source of carbon and energy, and especially strains isolated from marine water samples seem to incorporate only negligible amounts of methane carbon during methane oxidation (Jones \& Morita 1983).

The rates for methane oxidation by whole pogonophores (Table 2) cannot be directly compared with the measured nitrification rates by homogenates of Siboglinum poseidoni (Table 4). However, if the rates for homogenates of posterior parts are expressed in nmol $g^{-1}$ wet wt $h^{-1}\left(0.54 \mathrm{nmol} \mathrm{g}^{-1}\right.$ wet wt $\mathrm{h}^{-1}$ for $2.5 \mathrm{mM}$ ammonium sulphate and $1.43 \mathrm{nmol} \mathrm{g}^{-1}$ wet wt $\mathrm{h}^{-1}$ for $100 \mu \mathrm{mol}$ hydroxylamine) these rates can be compared to methane oxidation rates $\left(65.05 \mathrm{nmol} \mathrm{g}^{-1}\right.$ wet wt $\mathrm{h}^{-1}$ at a concentration of $11.9 \mu \mathrm{M}$ methane). 
To evaluate the possibility of ammonia oxidation by Siboglinum poseidoni symbionts it is necessary to consider the concentrations of methane and ammonia in the natural habitat of this pogonophore. Concentrations of methane in the sediment varied between 1 and $44 \mu \mathrm{mol} \mathrm{kg}{ }^{-1}$ wet wt (Schmaljohann \& Flügel 1987, Schmaljohann et al. 1990), whereas ammonia concentrations were between 123 and $724 \mu \mathrm{mol} \mathrm{kg} \mathrm{kg}^{-1}$ (Table 3). This means that ammonia concentrations were 1 to 2 orders of magnitude higher than methane concentrations. Dalton (1977) gives $K_{\mathrm{m}}$ (Michaelis constant) values for the methane monooxygenase of Methylococcus capsulatus of $160 \mu \mathrm{M}$ for methane and $96 \mathrm{mM}$ for ammonia. Ammonia oxidation in this methanotroph would therefore only be significant if there were either very much ammonia or very little methane in the sediment. In the sediment from the $S$. poseidoni site, with its low and varying methane concentrations, the possibility of switching from methane to ammonia oxidation might be advantageous to a sedentary organism.

Acknowledgements. The author thanks the Deutsche Forschungsgemeinschaft for funding this project, and Prof. W. Gunkel, Prof. G. Rheinheimer and Dr K.-O. Kirstein for critical reading of the manuscript.

\section{LITERATURE CITED}

Anderson, R. K., Scalan, R. S., Parker, P. L., Behrens, E. W. (1983). Seep oil and gas in Gulf of Mexico slope sediment. Science 222: 619-621

Anthony, C. (1982). The biochemistry of methylotrophs. Academic Press, London

Bradford, M. M. (1976). A rapid and sensitive method for the quantitation of microgram quantities of protein utilizing the principle of protein-dye binding. Analyt. Biochem. 72: $248-254$

Childress, J. J., Fisher, C. R., Brooks, J. M., Kennicutt II, M. C., Bidigare, R., Anderson, A. E. (1986). A methanotrophic marine molluscan (Bivalvia, Mytilidae) symbiosis: mussels fueled by gas. Science 233: 1306-1308

Dalton, H. (1977). Ammonia oxidation by the methane-oxidizing bacterium Methylococcus capsulatus strain Bath. Arch. Mikrobiol. 114: 273-279

Dando, P. R., Southward, A. J., Southward, E. C., Barrett, R. L. (1986). Possible energy sources for chemoautotrophic prokaryotes symbiotic with invertebrates from a Norwegian fjord. Ophelia 26: 135-150

Davidova, E. G., Zhivotchenko, A. G., Davidov, E. R., Rachins-

This article was presented by G. Rheinhermer, Kiel, Germany kii, V V (1988). Assimilation of carbon during growth of methane-oxidizing bacteria on a mixture of methane with ethane. Microbiology 57-300-305

Flügel, H. J., Langhof, I. (1983). A new hermaphroditic pogonophore from the Skagerrak. Sarsia 68: 131-138

Grasshoff, K. (1964). Über eine empfindliche, direkte Methode zur automatischen und manuellen Bestimmung von Ammoniak im Meerwasser. Z. analyt. Chem. 234: 13-22

Higgins, I. J., Best, D. I., Scott, D. (1982). Generation of products by methanotrophs. In: Hollaender, A. (ed.) Genetic engineering of microorganisms for chemicals. Bas. Life Sci. 19: 383-402

Jones, R. D., Morita, R. Y (1983). Methane oxidation by Nitrosococcus oceanus and Nitrosomonas europaea. Appl. environ. Microbiol. 45: 401-410

Leadbetter, E. R., Foster, J. W. (1960). Bacterial oxidation of gaseous alkanes. Arch. Mikrobiol. 35: 92-104

O'Neill, J. G., Wilkinson, J. F. (1977). Oxidation of ammonia by methane-oxidizing bacteria and the effects of ammonia on methane oxidation. J. gen. Microbiol. 100: 407-412

Romanovskaya, V A., Shurova, Z. P., Yurchenko, V V., Tkachuk, L. V., Malashenko, Y. R. (1977). Investigation of the ability of obligate methylotrophs for nitrification. Microbiology 46: 66-70

Schmaljohann, R., Faber, E., Whiticar, M. J., Dando, P. R. (1990). Co-existence of methane- and sulphur-based endosymbioses between bacteria and invertebrates at a site in the Skagerrak. Mar. Ecol. Prog. Ser. 61: 119-124.

Schmaljohann, R., Flügel, H. J. (1987). Methane-oxidizing bacteria in Pogonophora. Sarsia 72: 91-98

Southward, A. J., Southward, E. C., Dando, P. R., Barrett, R. L., Ling, R. (1986). Chemoautotrophic function of bacterial symbionts in small Pogonophora. J. mar. biol. Ass. U.K. 66: $415-437$

Stanley, S. H., Dalton, H. (1982). Role of ribulose-1,5-bisphosphate-carboxylase/oxygenase in Methylococcus capsulatus (Bath). J. gen. Microbiol. 128: 2927-2935

Stirling, D. J., Dalton, H. (1979). The fortuitous oxidation and cometabolism of various carbon compounds by whole-cell suspensions of Methylococcus capsulatus (Bath). Fedn eur. microbiol. Soc. (FEMS) Lett. 5: 315-318

Strickland, J. D. H., Parsons, T R. (1972). A practical handbook of seawater analysis, 2nd edn. Bull. Fish. Res. Bd Can. 167: 1-310

Ward, B. B. (1987). Kinetic studies on ammonia and methane oxidation by Nitrosococcus oceanus. Arch. Mikrobiol. 147: $126-133$

Wen, W. Y. Hung, J. H. (1970). Thermodynamics of hydrocarbon gases in aqueous tetraalkyl-ammonium salt solutions. J. phys. Chem., Wash. 74: 170-180

Whittenbury, R., Phillips, K. C., Wilkinson, J. F. (1970). Enrichment, isolation and some properties of methane-utilizing bacteria. J. gen. Microbiol. 61: 205-218

Wiesenberg, D. A., Guinasso, N. L., Jr (1979). Equilibrium solubilities of methane, carbon monoxide and hydrogen in water and seawater J. chem. engineering Data 24: 354-360

Manuscript first received: January 10, 1991

Revised version accepted: July 1, 1991 